\title{
More on the management of lateral neck ectopic thyroid tissue
}

\author{
Rafael Denadai, Luís Ricardo Martinhão Souto
}

Division of Plastic and Reconstructive Surgery, Department of Surgery, School of Medical Sciences, Universidade de Marilia (UNIMAR), Marilia, Brazil

We read with interest the review article by Ibrahim and Fadeyibi ${ }^{1}$ and have the following comments regarding the evaluation of lesions in ectopic thyroid. Although the authors ${ }^{1}$ point out that fine needle aspiration cytology (FNAC) is important when malignancy is suspected, in lateral neck ectopic thyroid tissue, without subsequent surgical resection, ${ }^{2}$ our group $^{3}$ and others ${ }^{4,5}$ have recommended the management of similar lesions in a different manner. While ultrasound-guided FNAC is generally accepted as a good tool for the diagnosis of non-pathological ectopic thyroid tissue in the neck, ${ }^{4}$ FNAC may be a source of diagnostic pitfalls for the cytopathologists in cases of co-existing malignacies. ${ }^{4}$ There are in fact reports describing neck malignancies which were initially evaluated by FNAC as being benign ectopic thyroid tissue and later proved to be papillary thyroid microcarcinomas. ${ }^{5}$ This is very important in view of the reported existence of primary papillary

Key words: Ectopic thyroid, Diagnosis, Surgery

\footnotetext{
Address for correspondence:

Rafael Denadai, M.D., Division of Plastic and Reconstructive Surgery, Department of Surgery, School of Medical Sciences, Universidade de Marília (UNIMAR), Paula Fabiana Tudela, 161 - Esmeralda 17516-707, Marília, São Paulo, Brazil,

Tel. / Fax: + 5514 3453-5456,

E-mail: denadai.rafael@hotmail.com

Received 18-04-12, Revised 10-05-12, Accepted 19-05-12
}

and follicular cancers arising only in an ectopic neck thyroid, with or without orthotopic thyroid gland. ${ }^{6,7}$ It thus appears that the correct differentiation between benign and malignant lesions may be reliably established only through rigorous criteria via histological assessment of surgically excised tissue blocks from the ectopic thyroid. ${ }^{3}$ Indeed, in order to exclude malignancy, nuclear characteristics such as groundglass appearance, irregularity of nuclear contours, grooves and pseudo-inclusions and capsular rupture and/or vascular invasion should be excluded through a detailed histopathological analysis. ${ }^{3}$

In short, FNAC should be used for the preoperative diagnosis of neck thyroid tissue. ${ }^{3-5}$ Moreover, regardless of the aspects (cosmetic reasons, when the swelling is symptomatic and does not respond to replacement therapy, or if malignancy is suspected) that indicate surgical resection of lateral neck ectopic thyroid as described by the authors, ${ }^{1}$ the recommended definitive treatment of these lesions is surgical excision with histopathological evaluation, ${ }^{3-7}$ while a substitution treatment with thyroxine must be carried out when necessary.,

Sources of funding: None
Conflict of interest: None

\section{REFERENCES}

1. Ibrahim NA, Fadeyibi IO, 2011 Ectopic thyroid: etiology, pathology and management. Hormones (Athens) 10: 261-269. 
2. Aalaa M, Mohajeri-Tehrani MR, 2012 Images in clinical medicine. Ectopic thyroid gland. N Engl J Med 366: 943.

3. Bersaneti JA, Silva RD, Ramos RR, Matsushita MdeM, Souto LR, 2011 Ectopic thyroid presenting as a submandibular mass. Head Neck Pathol 5: 63-66.

4. Paksoy N, 2007 Ectopic lesions as potential pitfalls in fine needle aspiration cytology: a report of 3 cases derived from the thyroid, endometrium and breast. Acta Cytol 51: 222-226.
5. Borges A, Martins M, André S, 2010 Double thyroid ectopia (with incidental papillary thyroid microcarcinoma) (2010: 8b). Eur Radiol 20: 2768-2771.

6. Cordes S, Nelson JJ, 2010 Papillary carcinoma arising in median ectopic thyroid tissue: management of the thyroid gland. Ear Nose Throat J 89: E4-7.

7. Guerrissi JO, 2012 Follicular variant of papillary carcinoma in submandibular ectopic thyroid with no orthotopic thyroid gland. J Craniofac Surg 23: 138-139. 